\title{
Acceptance of the Howland Award
}

\author{
Reflections on Pediatric Care
}

\author{
Louis K. Diamond
}

Department of Pediatrics, University of California, San Francisco Medical Center, San Francisco, California, USA

It is customary, when accepting this high honor, to acknowledge one's indebtedness to a number of people, and even to name some who contributed to the success of the career that is being recognized by this award. In my case, I wish to make clear that this is not a proforma statement. In the more than 4 decades of practicing and teaching pediatrics and pediatric hematology, I have been most fortunate in having associated with me dozens of bright young men and women, by last count, actually a half a dozen dozen (72), who, while learning as much as they could from my associates and me, repaid us by teaching us what we needed to know. They made us all the wiser by their questions, corrections, occasional criticisms, and sharing experiences. And experience is not necessarily, as Oscar Wilde stated, "the name everyone gives to his mistakes." In our cases, it was the accumulation of correct solutions which we recalled when next we were faced with similar problems. To the more than 70 trainees and fellows, assistants and associates - men and women, many of whom have reached professorial rank and have become leaders in pediatrics and pediatric hematology, and with whom I have enjoyed a long and very active career-I offer sincere thanks and a figurative share of this prize.

In considering a suitable topic for this talk, during the several anxious months since $I$ was first informed of my good fortune, I spent many an evening worrying the subject, like a puppy shaking an old boot, without coming to any comforting solution. Then I recalled my very first out-of-town lecture in 1928 and the advice of my teacher, Dr. Kenneth Blackfan. He had named me as a substitute for a talk he had promised, but was unable, to give at a local medical society in Upstate New York, near his home town. When I expressed to him my nervousness at talking to a group of experi- enced and older physicians, he told me that in giving lectures there were two important principles I should always keep in mind. The most important was the assurance that I knew more about my subject than any one in the audience and was better prepared to discuss it. If not, I had no business being on the platform. Since then, I have tried to overcome any uneasiness about giving a talk by convincing myself that I knew as much, if not more, about my subject than most, if not all, of the audience. But today, before this prestigious gathering of the brightest minds in pediatrics, I can certainly not claim to be the most knowledgeable on any matter. Therefore, my anxiety. After reviewing material that might fit Dr. Blackfan's prime dictum, I finally came to the conclusion that the only subject I should know better than any one else in the audience was myself.

However, Dr. Janeway has spared me the embarrassment of presenting a prejudiced personal history and with his usual generosity has given you an idealized view of my past. This frees me to present here the much more interesting story of my first chief, Dr. Blackfan, and his influence on pediatrics, on a generation of pediatricians, and on one pediatrician in particular. He was a master teacher and an exemplary practitioner who, in truly legendary "Horatio Alger" fashion, through hard work and constant perseverance against numerous handicaps, was able to reach the pinnacle of success in an academic career and enjoy the highest esteem of his associates, his students, and his patients.

Kenneth Daniel Blackfan was born in the small town of Cambridge, New York, about 30 miles above Albany; he attended local schools until he graduated from high school and then went on to Albany Medical College. As the third generation of physicians in his family, he expected and seemed destined to spend his life as a coun- 
try practitioner. But chance played an important part in drastically changing this.

To Albany Medical College in 1903 had come a new Chief of Pathology and Bacteriology, Dr. Richard Pearce, from Harvard Medical School, the University of Pennsylvania, and Leipzig. His influence on young Blackfan extended well beyond the medical school days since he had a summer home in nearby Dorset, Vermont, and Dr. Blackfan frequently visited him there. It must have been on Pearce's advice that, after 4 years, the young physician decided to give up general practice and enter the rapidly growing field of pediatrics. On Pearce's recommendation, he was accepted as resident physician at St. Vincent de Paul Foundling Home in Philadelphia. Here, his natural talent for helping children showed itself and his sound judgment, good sense, constant tact, and complete dependability were soon recognized. This led to his being offered the position of Chief Resident in St. Louis by the famous Dr. Howland, who when he himself moved to Baltimore, took Blackfan along, still in the position of Chief Resident, to the new Harriet Lane Home of the Johns Hopkins Hospital. Dr. Howland attracted to his department the brightest young men in medicine. They became the leaders in pediatrics in the next generation. As stated in The Bible (Genesis, Chapter 6, line 4), "There were giants in the earth in those days and they became mighty men ... men of renown." Practically every one of Howland's staff became the head of a pediatric department in a medical school.

In Howland's time chief residents were the working directors of their services, not just for one year, but for several. In those days the game of academic musical chairs did not proceed at a fast fox-trot with frequent stops, but rather like an endless slow waltz. In the Hopkins tradition, Blackfan spent 9 years as Chief Resident.

When he moved on, it was to accept the appointment of Professor and Chairman of the Pediatric Department at the University of Cincinnati Medical School. From there the next step up was not long in coming, for within 3 years, Kenneth Blackfan was named the Thomas Morgan Rotch Professor of Pediatrics at Harvard Medical School and Physician-in-Chief at the prestigious Children's and Infant's Hospitals in Boston, the positions Dr. Janeway now holds. This was a challenging post for his talents as a teacher, a clinician, a leader, and a diplomat, and he proved eminently successful in all these.

On teaching rounds, Dr. Blackfan's approach to a diagnostic problem seemed at first slow and meander- ing but soon, its clear logical progression would become evident, and when his reasoning reached its conclusion, the diagnosis was either definitely established or within reach. I recall vividly one of the first cases I heard him discuss when I was a senior medical student. In fact, I can even remember the patient's name, and diagnosis, so I was able recently to look up her old record and confirm this story. Dr. Blackfan's analysis of the history and the physical findings showed that the admitting diagnosis of rheumatic fever with painful tender joints was not tenable. He concluded that the child probably had chronic meningococcus meningitis. When the residents did the indicated lumbar puncture, they readily found the organisms in the pus cells. Treatment with antimeningococcus serum during the next 6 weeks led to a slow but dramatic complete recovery. From this and similar experiences at this time, the choice of a career in pediatrics was definitely made for me.

My earliest interest in hematology is also easily pinpointed. While I was serving as senior clinical clerk on the ward, a 4-year-old boy was brought in because of fever, swollen glands, and an enlarged spleen of 2 weeks' duration. Biopsy of an inguinal lymph node at the local hospital a few days earlier had suggested the diagnosis of malignant Hodgkin's disease. On admission to our ward, examination of the peripheral blood revealed over $35 \%$ unusual, large lymphocytes. Review of the lymph node sections cast doubt on the diagnosis of lymphoma and, at Dr. Blackfan's suggestion to me, search of the recent literature disclosed several articles describing cases of benign glandular fever with atypical lymphocytes in the blood. The diagnosis of what became known as infectious mononucleosis was then made. In the following week the spontaneous regression of the whole process left everyone much pleased, especially one well hooked future hematologist. Incidentally, this case presents still another unusual feature. Recently, under the stressful stimulus of this impending talk, I was able to recall the child's name and his home town in Connecticut. The record librarian found his old chart for me. The telephone company supplied the phone numbers of persons having the desired surname. The first person I called, to our mutual surprise, answered the childhood nickname I remembered. He reported he had been in good health and now had four grown children. Except for recurring cervical lymphadenopathy whenever he had a sore throat, which some of you might be able to explain, he had no residual of his childhood ailment. Here we have the story of the first recognized case of infectious mononucleosis at the Boston Children's Hospital and 
a follow-up report 46 years later, an infrequently documented dividend of a pediatrician's longevity.

My use of the term "future hematologist" was not lightly chosen. When I first consulted Dr. Blackfan about the possibility of developing in his department the subspecialty of hematology in which he had long been interested, he was most encouraging. He advised a period of training in basic research and then in clinical hematology, to be followed by a regular pediatric internship and residency before turning to specialization. This sounded ideal, because he offered to assist me in finding a place for the basic training and agreed to accept this 1-year experience in the laboratory in lieu of the usual requirement of an internship before the pediatric appointment on his service. However, I was presented with "food for thought" when he told me that there were no funds immediately available for any regular food regularly during the year of hematology training, and, even more disturbing, he suggested that, after the 2 or 3 years of my residency, it would be desirable that I do a few years of part-time private practice both for the experience and for financial support until I could begin to attract lucrative consultations in pediatric hematology. Since I would probably not be busy at first-a prophetic understatementthis would allow me plenty of free time to pursue hematologic problems in the hospital and in the laboratory. In other words, it was his belief that, in accord with the "Hopkins system," anyone planning a career in a combined academic and clinical position should be prepared to spend about 10 years in special training and in gaining experience. Remember, please, that training programs, special research fellowships, career development awards, and research career appointments had not even been dreamed of at this time. In fact, it would be over 20 years before the National Institutes of Health initiated such programs. Nevertheless, with Dr. Blackfan's encouragement, I undertook this commitment with the understanding that should my circumstances or inclinations dictate a change in plans after 3 years, meaning at the conclusion of the residency appointment to which I was committed, I would be free to make other arrangements without prejudice. Here, I wish to record my indebtedness to Dr. S. Burt Wolbach, then our professor of pathology, and especially to the late Dr. James L. Gamble, the head of our pediatric research division. They made available to me research funds, small by present standards, but adequate then, to support me partially and to employ a technician in our hematology laboratory.

Dr. Gamble was the mainstay of the research labo- ratory: a wise and ready counsellor, a generous provider of financial support in dire emergencies, always from anonymous sources, and a delightful host who with a story in a few well chosen words would make our regular afternoon teas in his laboratory study a refreshing break in the long day. I hardly need a reminder of those relaxing moments at tea-time, but should my memory begin to fail, I have but to look at the samovar used there, which Mrs. Gamble has generously given me, vividly to recall those wonderful days.

You should also know that in the lean years of my start in pediatrics, whenever I wondered whether I was on the right course and should continue, I was encouraged by just three words from my wife: "But, of course!".

Dr. Blackfan was a superb teacher, particularly at the bedside, but he never forgot or ignored the child's presence. He always emphasized the importance of caring for the patient as a whole, as a person, rather than as a disease state. He stressed the value of "total care" long before the term was used as a supposedly new approach to treatment of the individual by a group of specialists. Although he encouraged our calling on experts and consultants for advice and guidance in all problems touching on their special fields, for each of our patients we were the responsible physicians to whom they could relate at all times. Dr. Blackfan set us an example in this. I recall on one occasion accompanying him to the private ward for a first visit to an anemic, undernourished, anxious little girl with chronic colitis. After the Resident-in-Charge had introduced us and explained to the youngster that she would have several doctors caring for her different problems, she said "that's O.K., but who will take care of Me?" Dr. Blackfan assured her that although she might be examined by several doctors, she was his responsibility, that he'd see her daily or oftener until she'd get better, and as soon as possible he would send her home. This triple promise completely satisfied her and started her on the road to recovery as she told me years later. That was an example of total care as we were taught it.

Another now popular expression was also introduced into our everyday vocabulary many years ago by Dr. Blackfan and his Head Nurse on the Infant's Ward, Miss Kathryn MacKenzie, the late Mrs. Edwin T. Wyman. In discussing the treatment of a neglected malnourished infant, a distressingly persistent ruminator, they both emphasized that what this child needed most was constant attention and "tender loving care". "TLC, q.s. (quantum sufficit or as much as needed)" 
became a frequently appearing entry in the order book to the mystification of new personnel on the service. Now, of course, it is a commonly used expression and has even been taken over by the advertising agencies to sell cosmetics or maybe unmentionables. No wonder the phrase lost its meaning and value. Incidentally, the same Miss MacKenzie insisted that the resident's first days on her wards include instruction and practice in feeding infants, changing diapers, and bathing and "fathering" crying babies. I'm sure Gloria Steinem would have approved. Unfortunately, the importance of "tender loving care" may have failed to carry over into the home. Often it was probably replaced by material gifts, leaving unfulfilled the emotional needs of the child. This unfulfilled need may be related in recent times to the large number of adolescents and late teenagers leaving their homes and their usual environments to seek companionship and TLC or a poor facsimile of it in new and different surroundings. The so-called "flower children" or "street people" took to standing in close embrace, or walking along clutching each other, much as small insecure children hug their ragged, shaggy, dishevelled teddy bears; and, you know, some of them don't look much different, either. Maybe TLG should be trade-marked by pediatrics, taken out of the hands of the advertising agencies, and put back into the homes where it often is so sorely needed.

Dr. Blackfan's frequent, usually daily, ward rounds were made in small informal groups walking from bed to bed. However, his semiweekly Grand Rounds, one day on the infant's wards and another on the children's were always attended by his whole staff and were often large and just a bit formal. Even so, they were essentially teaching rounds with the cases chosen for this purpose rather than for presenting unusual and rare diagnostic features. He also enjoyed, whenever his schedule permitted, the contact with junior medical students in the introduction to the clinic exercises and favored having senior staff men share this responsibility. Frequently, in using out-patient facilities for teaching, a medical student would apologetically present as his case a "perfectly normal average infant," apparently offering little material for discussion. This pleasant challenge almost always permitted Dr. Blackfan to uncover missed imperfections, a few abnormalities, or some unusual features-possibly some better than average accomplishment, to the gratification of the child's parent. As we tried to point out then, even the 100-generation inbred mice of the Jackson Laboratory in Bar Harbor are not invariably ex- actly alike. The discovery of differences, of mutations, and of genetic variants keeps that laboratory in business. In the pediatric clinic our students soon learned to enjoy the challenge of detecting variations from the normal.

Although he was essentially conservative, Kenneth Blackfan did not oppose change. He had to feel certain however that it represented improvement over the status quo. And then the change had to be made so slowly as to be hardly perceptible. It was through such careful transitional structuring that he was able to effect the merger of the Infant's and the Children's Hospitals, originally separate corporate entities, to take over responsibility for, and control of, the Newborn Service at the Lying-In Hospital, to draw the Wellesley Convalescent Home into the Children's Hospital complex, and to lay the groundwork for what was to become a complete medical center for children. In Dr. Blackfan's world, progress was slow but certain. It was evolution, not revolution. He would have liked, as I do, the comfort and assurance of Lancelot Hog. ben's phrase: "the inevitability of gradualness."

Some time ago, when talking to a group of science students about the attractions of a medical career, their questions regarding the future made me realize $\mathbf{I}$ had been most fortunate to be in medicine during this era of its greatest advances-its great leap forward. The introduction of new and effective therapeutic regimes and the opportunities for discovering new disease entities and developing new concepts of the etiology and pathogenesis of old diseases seemed to be limitless. One example of this is worth special mention. The earliest recognized patients with thalassemia major were originally diagnosed as "atypical" von Jaksch's anemia, with very little justification, considering they were children of Greek, not German parentage such as von Jaksch had described; they also had other "atypical" features such as marked splenomegaly, peculiar facies, and unusual bone changes by x-ray. In Boston, they were hidden under the diagnosis of "atypical" familial hemolytic anemia. Although thalassemia must have been present for many generations in young children living in the Mediterranean littoral, it was probably considered there to be an "atypical" form of malaria. Astute observations made by Dr. Thomas Cooley on four Greek children in Detroit and one in Boston led to his report in 1927 of this distinct and different disease entity. This eventually opened up an entirely new field of study in hematology, the hemoglobin abnormalities. Beginning with only two examples, thalassemia and sickle cell anemia, there 
are now more than 200 types of quantitative and qualitative disorders of hemoglobin synthesis. Such experiences repeatedly led us to question any diagnosis of an "atypical" form of a disease. What is atypical of a typical disease entity is more likely typical of a different condition. This may sound confused, but the maxim has proved valuable on numerous occasions.

Throughout most of my years in medicine, opportunity and support, both intellectual and financial, were readily and liberally available. Now unfortunately, the biblical "7 years of plenty" (Genesis: 41, 29) seem to be ending and the lean years threaten to overtake us. Hopefully the deleterious effects of this threatened malnutrition of science will soon be recognized by the powers-that-be. The 7 lean years might then be reduced to only 3 or 4 , depending on the next election. Returning to the students' questions about the changing patterns in medicine, how can one answer the valid criticism that medical practice has become too mechanized, too specialized, too impersonal, and too expensive? When I asked one questioner what he himself would do about it, his reply was decisive. Said he: "I'm going into engineering." However, others expressed a desire to practice among the poor and underprivileged, and I thought the trend was toward greater interest in the health of the individual which would have pleased Kenneth Blackfan whose prime concern was always the care of the patient.

At this time, I should mention the other important principle Dr. Blackfan told me when I was scheduled to give my first lecture. He said: "Don't make your talk too long. Some members probably are anxious to complete their scheduled calls and relieve the anxieties of their waiting patients. Keep an eye on the secretary or the chairman. When he begins to look at his watch and gets restless, your time is probably up. Without further delay, begin your concluding remarks." In the present case, I know that our chairman and our secretary are anxious to keep to the scheduled program and relieve the anxieties of their waiting essayists. I therefore hasten to close with the hope that this talk has not left you only with the impression that I am in my anecdotage, but that some of the old practices like thoughtful, individualized, considerate care of children are still the basis of good pediatrics. Only by practicing this can we fulfill our function, retain the affection and respect of our patients and their families and regain our authority and prestige in the community.

My final wish is expressed by the traditional greeting and farewell of people throughout the world: shalom alechem: peace be with you.

$$
\therefore \quad \text { Notes }
$$

1. This address was presented at the Annual Meeting of the American Pediatric Society, San Francisco, May 18, 1973.

2. Dr. Louis K. Diamond is Professor of Pediatrics, University of California, San Francisco, Calif., and Professor of Pediatrics, Emeritus, Harvard University, Boston, Mass.

3. Requests for reprints should be addressed to: Lours $\mathrm{K}$. Diamond, M.D., Department of Pediatrics, University of California, San Francisco Medical Center, San Francisco Calif. 94143 (USA).

4. Received for publication June 7, 1973. 